\title{
Stability of an infectious pancreatic necrosis virus (IPNV) isolate stored under different laboratory conditions
}

\author{
Stein H. Mortensen*, Roald Kåre Nilsen, Brit Hjeltnes \\ Institute of Marine Research, Department of Aquaculture, PO Box 1870, Nordnes, N-5024 Bergen, Norway
}

\begin{abstract}
An infectious pancreatic necrosis virus (IPNV) belonging to the Sp serotype, isolated from scallops Pecten maximus, was propagated and suspended in sterile water and cell culture medium with different salinities and incubated at temperatures ranging from -80 to $40^{\circ} \mathrm{C}$. Virus stability was examined by measuring virus titers under different storage conditions. Virus titers were also measured after repeated freezing and thawing, and in incubated sterile filtered scallop hepatopancreas, haemolymph and crystalline style samples, and salmon Salmo salar kidney homogenate. The virus was stable under most storage conditions. Temperatures ranging from -80 to $+20^{\circ} \mathrm{C}$, as well as salinities from 0 to $40 \%$, did not seem to influence the stability of the virus. A reduction was observed above $20^{\circ} \mathrm{C}$. Each freezing and thawing procedure resulted in a reduction of the virus titer. This reduction was larger at -80 than at $-20^{\circ} \mathrm{C}$. The IPNV persisted for a long period in sterile filtered scallop haemolymph, dissolved crystalline style and hepatopancreas. In kidney homogenate from IPNV-infected salmon the virus titers were reduced at least 10-fold during the first day of incubation at all temperatures tested. When virus was propagated in cell culture and subsequently mixed with non-infected salmon kidney homogenate, the virus proved more persistent. Our results illustrate the importance of rapid and standardised laboratory processing of potentially virus-containing tissue samples, and are relevant when considering laboratory storage of samples containing IPNV.
\end{abstract}

KEY WORDS: Infectious pancreatic necrosis virus (IPNV) Stability $\cdot$ Storage $\cdot$ Scallops $\cdot$ Tissue homogenate

The aquatic birnavirus group, including the fish pathogenic infectious pancreatic necrosis virus (IPNV), consists of viruses which are considered very stable in water and under most storage conditions. Disease transmission in aquaculture is a matter of great concern, and the dynamics of horizontal transmission of an aquatic pathogen must take into consideration the stability of the agent in water. Although virus may be

•E-mail: stein.mortensen@imr.no inactivated or practically eliminated by physical dilution in water, such dispersal of a persistent virus may carry with it the risk of disease transmission.

High concentrations of IPNV can be found in water during outbreaks of infectious pancreatic necrosis (IPN) (Desautels \& MacKelvie 1975, Ahne et al. 1989). Ahne (1980) found IPNV in water samples from a lake in the absence of an IPN outbreak. IPNV was found in faeces of carrier fish (Billi \& Wolf 1969, Yamamoto 1975) and contaminated crustaceans such as the freshwater crayfish Astacus astacus (Halder \& Ahne 1988). The virus was also present in tissues of dead specimens. Virus and virus-contaminated material may, as discussed by Desautels \& MacKelvie (1975), flow downstream from a contaminated site and has been detected as far as $19.3 \mathrm{~km}$ downstream from the effluents of IPNV-contaminated fish hatcheries (McAllister \& Bebak 1997).

Most studies of IPNV transmission have been performed in freshwater systems, but there is no obvious reason to believe that dispersal of virus and contaminated material is any different in seawater. IPNV-like aquatic birnaviruses do cause diseases in marine fish species and have been isolated from an increasing number of marine fish and invertebrate species (Stephens et al. 1980, Bonami et al. 1983, McAllister et al. 1983, Schutz et al. 1984, Mortensen et al. 1990). Presumably, virus dispersal may occur via currents which run through affected fish farms.

Water-born virus may be accumulated in filterfeeding animals, and there are numerous studies which show that bivalve molluscs rapidly accumulate virus from contaminated water, sometimes in concentrations higher than in the surrounding water (Gerba \& Goyal 1978). IPNV-like aquatic birnaviruses have been isolated from mussels Mytilus edulis (authors' unpubl. data) and scallops Pecten maximus in Norway (Mortensen et al. 1990). These isolations could have 
been due to contaminations from virus-contaminated water.

The aim of the present work was to describe the stability of a scallop IPNV isolate stored under different laboratory conditions in water and contaminated fish and scallop tissues.

Materials and methods. Virus and cell culture: The virus used was an IPNV isolated from Norwegian scallops Pecten maximus (Mortensen et al. 1990). The Chinook Salmon Embryo (CHSE) cell line (Lannan et al. 1984) was used for virus propagation, detection and titration. Cells were cultured at $20^{\circ} \mathrm{C}$ in Earle's modification of Minimum Essential Medium (EMEM) (Bio-Whittaker) containing foetal bovine serum $(10 \%)$, non-essential amino acids (1\%) (Bio-Whittaker), L-glutamine (2 mM) (Bio-Whittaker) and Gentamicin solution (25 $\mathrm{mg} \times \mathrm{l}^{-1}$ ) (Bio-Whittaker). All plates were prepared the day before use.

Animals: Wild scallops Pecten maximus with a shell height of 10 to $12 \mathrm{~cm}$ were collected from the Sotra region, west of Bergen, and kept in aquaria with running filtered seawater at 9 to $10^{\circ} \mathrm{C}$. Farmed Atlantic salmon Salmo salar with a mean weight of $360 \mathrm{~g}$ were used. The fish were fed commercial dry pellets and were kept in tanks with rumning, UVtreated seawater at 9 to $10^{\circ} \mathrm{C}$, until the fish were challenged.

Virus titrations: Virus titrations were performed by end-point dilution on loosely confluent cell layers in 96-well Nunclon microtiterplates using 12 parallel wells per dilution. The cell layers were examined for cytopathogenic effect (CPE) $6 \mathrm{~d}$ after inoculation. Virus titers were calculated as TCID $50 \mathrm{ml}^{-1}$ or TCID 50 $\mathrm{g}^{-1}$ tissue using the method of Reed \& Muench (1938). If the CPE was questionable, supernatants from the wells were inoculated onto fresh cell cultures and incubated another $6 \mathrm{~d}$ before new examination.

Results. Stability of IPNV under different conditions of salinity and temperature: Virus at an initial infecivity of $10^{7.1} \mathrm{TCID}_{50} \mathrm{ml}^{-1}$ was incubated in sterile water or reconstituted seawater (Ultramarine Synthetic sea salt from Waterlife Research Industries Ltd) with salinities ranging from 0 to $40 \%$. The virus was incubated at temperatures ranging from
-80 to $20^{\circ} \mathrm{C}$, and at the specified intervals, aliquots of the infected water were removed and assayed for infectious virus. Under most storage conditions, there was no reduction in virus titer for as long as $121 \mathrm{~d}$ (Fig. 1). However, a clear reduction was observed at 30 and $40^{\circ} \mathrm{C}$, at which temperatures no viable virus was detectable after $78 \mathrm{~d}$ and $36 \mathrm{~d}$ of incubation respectively
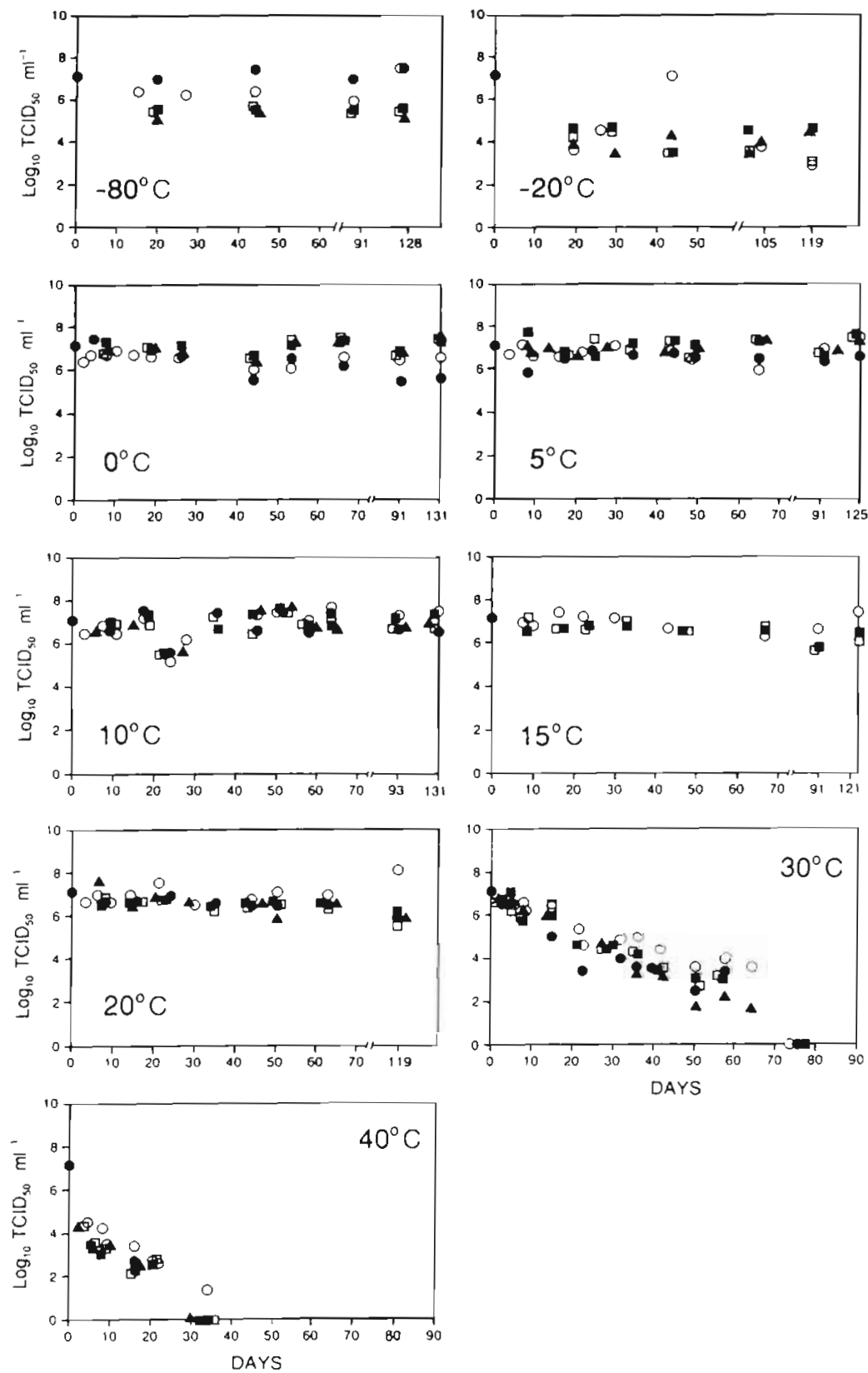

Fig. 1. Titers of an infectious pancreatic necrosis virus (IPNV) isolated from the scallop Pecten maximus as $\log$ TCID $_{50} \times \mathrm{ml}^{-1}$ after incubations diluted 1:10 in Earle's Minimum Essential Medium (EMEM) cell culture medium ( $\bullet$ ), distilled water with a salinity of $0 \%(0)$ and artificial seawater (Ultramarine Synthetic Sea salt) with a salinity of $14(\mathbf{\square}), 27(\mathrm{a})$ and $40(\mathbf{\Delta}) \%$, respectively, at temperatures ranging from -80 to $40^{\circ} \mathrm{C}$ 


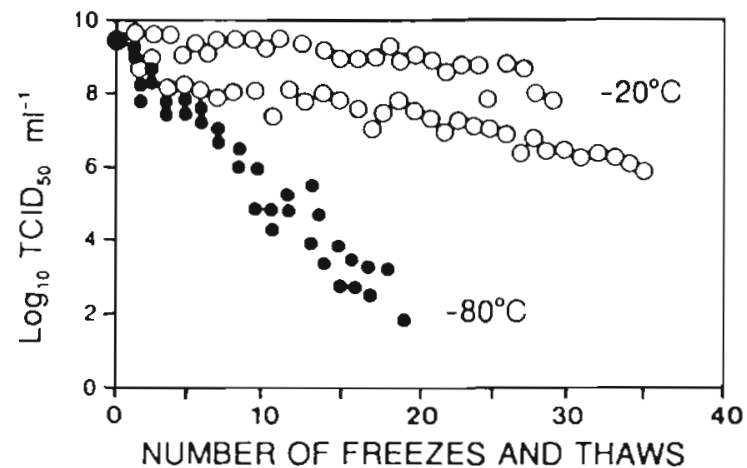

Fig. 2. Virus titers of 2 parallel suspensions of the scallop IPNV isolate (as $\log \mathrm{TCID}_{50} \mathrm{ml}^{-1}$ ) diluted 1:10 in EMEM cell culture medium after an increasing number of freezing and thawing procedures at -20 and $-80^{\circ} \mathrm{C}$

Virus was sensitive to repeated freezing and thawing. Weekly freeze-thawing episodes over a period of 36 wk were conducted for duplicate samples of virus with an original titer of $10^{95} \mathrm{TCID}_{50} \mathrm{ml}^{-1}$. The reduction in titer was much more drastic for virus stored at $-80^{\circ} \mathrm{C}$ than at $-20^{\circ} \mathrm{C}$ (Fig. 2).

Stability of virus in scallop or salmon tissue extracts: Virus was incubated in homogenates of the scallop hepatopancreas and crystalline style, and in the haemolymph. Virus was also incubated in salmon kidney tissue homogenate, and recovered from kidney tissue of IPNV-inoculated salmon (Table 1).

Discussion. The scallop isolate used in these experiments is a IPNV field strain belonging to the Sp serotype (Mortensen et al. 1990, Biering et al. 1997). This isolate caused infections and focal pancreatic necrosis in trout Salmo trutta under experimental conditions (Mortensen 1993) but appeared non-pathogenic for adult scallops (Mortensen et al. 1992). It has been hypothesised that the isolates from scallops may be the result of environmental contamination. The present results support this hypothesis. They show that the virus persists for a long time in water, as well as in scallop haemolymph, and indicate that IPNV might not be inactivated at all by enzymes in the scallop crystalline style, and inactivated only slowly in the digestive system. The finding that the virus reduction is far more rapid in a hepatopancreas homogenate than in hepatopancreas of live scallops (Mortensen et al. 1992) may also support the results showing long-term persistence of virus in live bivalve molluscs.

During IPN epizootics, IPNV concentrations in the water may reach levels which are more than sufficient to infect fish and fish eggs (Ahne et al. 1989). Up to $10^{5} \mathrm{TCID}_{50} \mathrm{ml}^{-1}$ water have been detected in troughs with trout fry during an epizootic (Desautels \& MacKelvie 1975). A number of articles describe the stability of IPNV in water (reviewed by Wolf 1988). Our results are consistent with the general conclusion that IPNV is stable under most laboratory storage and test conditions, including freezing and refrigeration (MacKelvie $\&$ Desautels 1975, Wolf 1988). Salinities between 0 and $40 \%$ seemed to have no influence on the stability of the virus, and in water, temperature influenced stability only above $20^{\circ} \mathrm{C}$. As reviewed by Bitton (1980) temperature is the most important physical factor influencing the stability of viruses, and most incubations in the present study indicated a temperature-dependent virus reduction. It is noteworthy that the virus survived for several weeks at $40^{\circ} \mathrm{C}$, a temperature close to the body temperature of birds and mammals. Although

Table 1. Titers of IPNV (as log TCID $50 \mathrm{ml}^{-1}$ or TCID $50 \mathrm{~g}^{-1}$ tissue) of samples incubated in: homogenised hepatopancreas from scallops inoculated with an IPNV suspension, haemolymph from the same inoculated scallops, scallop haemolymph with IPNV added, dissolved scallop crystalline style with IPNV added, homogenised kidney tissues from infected salmon, salmon kidney homogenate with IPNV added, and sterile filtered seawater with IPNV added (control). Positive IPNV detections below the level of titration (approx. $1.4 \mathrm{log}$ $\mathrm{TCID}_{50} \times \mathrm{ml}^{-1}$ ) are marked '-'. ND: negative samples

\begin{tabular}{|c|c|c|c|c|c|}
\hline Sample tissue & Starting titer & $4 \mathrm{~d}$ & $20 \mathrm{~d}$ & $60 \mathrm{~d}$ & $130 d$ \\
\hline \multicolumn{6}{|c|}{$\begin{array}{l}\text { Scallop hepatopancreas } \\
\text { from infected scallops }\end{array}$} \\
\hline $5^{\circ} \mathrm{C}$ & 7.6 & 7.3 & 5.5 & 3.5 & - \\
\hline $10^{\circ} \mathrm{C}$ & 7.6 & 7.3 & 6.7 & 4.0 & - \\
\hline $20^{\circ} \mathrm{C}$ & 7.6 & 7.4 & 6.6 & 3.5 & 3.8 \\
\hline \multicolumn{6}{|c|}{$\begin{array}{l}\text { Scallop haemolymph } \\
\text { from infected scallops }\end{array}$} \\
\hline $5^{\circ} \mathrm{C}$ & 6.3 & 6.4 & 5.8 & 6.5 & 6.1 \\
\hline $10^{\circ} \mathrm{C}$ & 6.3 & 6.6 & 5.6 & 6.0 & 5.9 \\
\hline $20^{\circ} \mathrm{C}$ & 6.3 & 6.6 & 6.0 & 4.6 & 3.4 \\
\hline \multicolumn{6}{|c|}{$\begin{array}{l}\text { Scallop haemolymph, } \\
\text { seeded samples }\end{array}$} \\
\hline $5^{\circ} \mathrm{C}$ & 6.8 & 6.1 & 6.3 & 6.2 & - \\
\hline $10^{\circ} \mathrm{C}$ & 6.8 & 6.2 & 6.2 & 5.8 & 5.8 \\
\hline $20^{\circ} \mathrm{C}$ & 6.8 & 5.8 & 6.1 & 6.3 & 5.2 \\
\hline \multicolumn{6}{|c|}{ Scallop crystalline style } \\
\hline $5^{\circ} \mathrm{C}$ & 6.7 & 6.3 & 5.8 & 4.9 & 3.6 \\
\hline $10^{\circ} \mathrm{C}$ & 6.7 & 6.8 & 6.0 & 4.9 & 3.8 \\
\hline $20^{\circ} \mathrm{C}$ & 6.7 & 6.8 & 5.9 & 5.4 & 2.5 \\
\hline \multicolumn{6}{|c|}{$\begin{array}{l}\text { Salmon kidney homo- } \\
\text { genate, infected fish }\end{array}$} \\
\hline $5^{\circ} \mathrm{C}$ & 5.3 & - & - & ND & ND \\
\hline $10^{\circ} \mathrm{C}$ & 5.3 & - & _- & ND & ND \\
\hline $20^{\circ} \mathrm{C}$ & 5.3 & - & - & ND & ND \\
\hline \multicolumn{6}{|c|}{$\begin{array}{l}\text { Salmon kidney homo- } \\
\text { genate, seeded samples }\end{array}$} \\
\hline $5^{\circ} \mathrm{C}$ & 7.8 & 6.9 & 4.0 & 2.8 & 1.9 \\
\hline $10^{\circ} \mathrm{C}$ & 7.8 & 7.7 & 7.1 & 4.7 & 1.7 \\
\hline $20^{\circ} \mathrm{C}$ & 7.8 & 7.7 & 7.3 & 4.6 & 1.8 \\
\hline \multicolumn{6}{|c|}{ Seawater (control) } \\
\hline $5^{\circ} \mathrm{C}$ & 6.7 & 6.3 & 6.3 & 6.5 & 6.0 \\
\hline $10^{\circ} \mathrm{C}$ & 6.7 & 6.5 & 6.5 & 6.3 & 6.0 \\
\hline $20^{\circ} \mathrm{C}$ & 6.7 & 5.7 & 5.9 & ND & 3.8 \\
\hline
\end{tabular}


factors other than temperature will influence the stability of a virus in a homeothermic gastrointestinal tract, the present results show that temperature itself is not a barrier for the passage of IPNV through homeothermic animals. This is in accordance with results which showed that IPNV does retain its infectivity after passage through birds, minks and cows (Sonstegard \& McDermott 1972, Eskildsen \& Vestergaard Jørgensen 1973, Smail et al. 1993). McAllister \& Owens (1992) showed that IPNV could be isolated from the faeces of a variety of wild piscivorous birds near fish hatcheries, and IPNV has been transmitted to trout fry by contaminating their water with faeces from herons which were fed IPNV-containing fish (Peters \& Neukirch 1986).

The tolerance of aquatic birnaviruses to freezing and thawing has been reported to be extremely variable between strains (McMichael et al. 1975). Although laboratory and natural conditions are indeed different, the present results may indicate that IPNV dispersed in nature remain infectious after long periods of time, and under extreme temperature conditions. Even though the stability observed in the present study was in general accordance with previous studies, e.g. Wedemeyer et al. (1978) and Ahne (1982), the results might seem to diverge from previously observed reduction of titers of incubated IPNV samples (Desautels \& MacKelvie 1975, Baudouy \& Castric 1977, Toranzo et al. 1983). The present results also seem to be in contrast to the observations that temperature has a greater influence on the viability of IPNV in freshwater than in seawater and that influence of salinity is more important at $15^{\circ} \mathrm{C}$ than at $20^{\circ} \mathrm{C}$ (Barja et al. 1983). Although the effect of the salinity observed by Barja et al. (1983) might be attributable to the presence of electrolytes, strain differences and an effect due to the microflora and -fauna in the water samples [as discussed by Desautels \& Mackelvie (1975) and Toranzo \& Hetrick (1982)] seems a more likely explanation. Results from trials using different virus strains and different natural water samples might therefore hardly be comparable.

When IPN virus was grown in cell culture and then mixed with non-infected salmon head kidney homogenate, the virus was more persistent than in homogenates from virus-inoculated fish. This observation may indicate that virus-inactivating factors, like circulating neutralising antibodies, produced in the infected fish are active in the sterile filtered kidney tissue homogenate. Frequently, in fish disease diagnostics, a large number of samples have to be processed. Sterile filtered homogenate may be left overnight to be added onto a cell culture the next day. Our experiments with IPNV-infected salmon showed that the virus titers were reduced at least 10 -fold during the first day of incubation at all temperatures tested. After $2 d$ the titer was reduced by a factor of 100 . The present results have thus shown the importance of immediate and standardised laboratory processing of poientially virus-containing tissue samples and may also be relevant when considering laboratory storage of samples containing IPNV.

Acknowledgements. The authors are grateful to Lisbeth Harkestad for excellent technical assistance and to Johan Glette for comments on the manuscript. This work was funded by The Norwegian Research Council.

\section{LITERATURE CITED}

Ahne W (1980) Vorkommen des Virus der infektiösen Pankreasnekrose der Forellen (IPN) bei verschiedenen Fischarten. Berl Münch Tierärztl Wochenschr 93:14-16

Ahne W (1982) Vergleichende Untersuchungen über die Stabilität von vier fischpathogenen Viren (VHSV, PFR, SVCV, IPNV). Zentralbr Veteriaermed B 29:457-476

Ahne W, Kelly RK, Sclotfeldt HJ (1989) Factors affecting the transmission and outbreak of infectious pancreatic necrosis (IPN). In: Lillelund $K$, Rosenthal $\mathrm{H}$ (eds) Fish health protection strategies. Federal Ministry for Research and Technology, Hamburg/Bonn, p 19-67

Barja JL, Toranzo AE, Lemos ML, Hetrick FM (1983) Influence of water temperature and salinity on the survival of IPN and IHN viruses. Bull Eur Assoc Fish Pathol 3(4):47-50

Baudouy AM, Castric J (1977) Persistance du pouvoir pathogène du virus de la nécrose pancréatique infectieuse après un séjour prolongé dans l'eau. Bull Off Int Epizoot $87: 409-413$

Biering E, Melby HP, Mortensen SH (1997) Sero and genotyping of some Norwegian aquatic birnavirus isolates. Dis Aquat Org 28:169-174

Billi JL, Wolf K (1969) Quantitative comparison of peritoneal washes and faeces for detecting infectious pancreatic necrosis (IPN) virus in carrier brook trout. J Fish Res Bd Can 26:1459-1465

Bitton G (1980) Introduction to environmental virology. Wiley \& Sons, New York

Bonami JR, Cousserans F, Weppe M, Hill BJ (1983) Mortalities in hatchery-reared sea bass fry associated with a birnavirus. Bull Eur Assoc Fish Pathol 3:41

Desautels D, MacKelvie RM (1975) Practical aspects of survival and destruction of infectious pancreatic necrosis virus. J Fish Res Bd Can 32:523-531

Eskildsen UK, Vestergaard Jørgensen PE (1973) On the possible transfer of trout pathogenic viruses by gulls. Riv Ital Piscic Ittiop A 8(4): 104-105

Gerba CP, Goyal SM (1978) Detection and occurrence of enteric viruses in shellfish: a review. J Food Prot 41(9): $743-754$

Halder M, Ahne W (1988) Freshwater crayfish - a vector for infectious pancreatic necrosis virus (IPNV). Dis Aquat Org $4: 205-209$

Lannan CN, Winton JR, Fryer JL (1984) Fish cell lines: establishment and characterization of nine cell lines from salmonids. In Vitro 20:671-676

Mackelvie RM, Desaultes D (1975) Fish viruses-survival and inactivation of infectious pancreatic necrosis virus. J Fish Res Bd Can 32:1267-1273 
McAllister PE, Bebak J (1997) Infectious pancreatic necrosis virus in the environment: relationship to effluent from aquaculture facilities. J Fish Dis 20:201-207

McAllister PE, Newman LW, Sauber JH, Owens WJ (1983) Infectious pancreatic necrosis virus; isolation from southern flounder, Paralichthys lethostigma, during an epizootic. Bull Eur Assoc Fish Pathol 3:37-38

McAllister PE, Owens WJ (1992) Recovery of infectious pancreatic necrosis virus from the faeces of wild piscivorous birds. Aquaculture 106:227-232

McMichael J, Fryer JL, Pilcher KS (1975) An antigenic comparison of three strains of infectious pancreatic necrosis virus of salmonid fishes. Aquaculture 6:203-210

Mortensen SH (1993) Passage of infectious pancreatic necrosis virus (IPNV) through invertebrates in an aquatic food chain. Dis Aquat Org 16:41-45

Mortensen SH, Bachere E, LeGall G, Mialhe E (1992) Persistence of infectious pancreatic necrosis virus (IPNV) in scallops (Pecten maximus). Dis Aquat Org 12:221-227

Mortensen SH, Hjeltnes B, Rødseth OM, Krogsrud J, Christie KE (1990) Infectious pancreatic necrosis virus, serotype N1 isolated from Norwegian turbot (Scopthalmus maximus), halibut (Hippoglossus hippoglossus) and scallops (Pecten maximus). Bull Eur Ass Fish Pathol 10(2):42-43

Peters F, Neukirch M (1986) Transmission of some fish pathogenic viruses by the heron, Ardea cinerea. J Fish Dis 9: 539-544

Reed LJ, Muench H (1938) A simple method of estimating fifty percent end points. Am J Hyg 27:493-497

Schutz M, May EB, Kraeuter JN, Hetrich FM (1984) Isolation of infectious pancreatic necrosis virus from an epizootic

Editorial responsibility: Jo-Ann Leong,

Corvallis, Oregon, USA occurring in cultured striped bass, Morone saxatilis (Walbaum). J Fish Dis 15:77-83

Smail DA, Irwin N, Harrison D, Munro ALS (1993) Passage and survival of infectious pancreatic necrosis (IPN) virus in the cow's gut after feeding a silage mixture containing IPN virus. Aquaculture 113:183-187

Sonstegard RA, McDermott LA (1972) Epidemiological model for passive transfer of IPN virus by homeotherms. Nature 237:104-105

Stephens EB, Newman MW, Zachary AL, Hetrick FM (1980) A viral aetiology for the annual epizootics of Atlantic menhaden, Brevoortia tyrannus (Latrobe) in Chesapeake Bay. $J$ Fish Dis 3:387-398

Toranzo AE, Barja JL, Lemos ML, Hetrick FM (1983) Stability of infectious pancreatic necrosis virus (IPNV) in untreated, filtered and autoclaved estuarine water. Bull Eur Assoc Fish Pathol 3(4):51-53

Toranzo AE, Hetrick FM (1982) Comparative stability of two salmonid viruses and poliovirus in fresh, estuarine and marine waters. J Fish Dis 5:223-231

Wedemeyer GA, Nelson NC, Smith CA (1978) Survival of the salmonid viruses infectious hematopoietic necrosis virus (IHNV) and infectious pancreatic necrosis virus (IPNV) in ozonated, chlorinated, and untreated waters. J Fish Res Bd Can 35:875-879

Wolf K (1988) Fish viruses and fish viral diseases. Comstock Publ Ass, Cornell Univ Press, Ithaca

Yamamoto T (1975) Frequency of detection and survival of infectious pancreatic necrosis virus in a carrier population of brook trout (Salvelinus fontinalis) in a lake. J Fish Res Bd Can 32(4):568-570

Submitted: September 9, 1997; Accepted: January 29, 1998 Proofs received from author(s): March 20,1998 